\title{
T THAT THE MEMBERSHIP HAS TAUGHT? NATIONAL IDENTITY CONSTRUCTION IN LITHUANIAN PUBLIC DISCOURSE AFTER ACCESSION TO THE EUROPEAN UNION ${ }^{1}$
}

\section{Andrius Švarplys}

Vytautas Magnus University, Department of Political Science, E-mail: a.svarplys@pmdf.vdu.lt

\section{Acknowledgments}

This paper has been presented at the Third International Conference on Nordic and Baltic Studies in Romania: European Networks: the Balkans, Scandinavia and the Baltic World in a Time of Crisis hosted by the Romanian Association for Baltic and Nordic Studies and Valahia University of Târgoviste, and sponsored by the Romanian National Research Council, May 25-27, 2012.

\begin{abstract}
:
'Europe' and 'Russia' have historically been the most remarkable landmarks, playing geopolitical, cultural, and moral guide-role in the construction of national collective identities in the Central Eastern European countries, including Lithuania. This 'civilizational identity' helped to unite Lithuanian political elites as well as society towards the direction to West and Europe after the collapse of Soviet Union. The question article addresses is: does the factual belonging to the European Union after the $1^{\text {st }}$ May, 2004 give the impulse to re-define 'Europe' and 'Russia' as the old essentials of collective identity of Lithuanians? The article presents the research based on monitoring of national public discourse (five Lithuanian national newspapers) in 2004-2007, i.e. enjoying three years of membership in the European Union and NATO.

The main result is that the role of Russia in the Lithuanian collective identity has not changed and still continues to play the major threat. The membership in the European Union and NATO has not solved Lithuanian security problem. According to the perceived threat, Russia has started to penetrate softly into Lithuania's economy (especially energy sector) and has silently begun to make an
\end{abstract}

\footnotetext{
1 This research was funded by a grant (No. MIP-026/2011) from the Research Council of Lithuania.
} 
impact to the domestic political parties and political elite. The traditional role of Europe, however, is slowly but gradually shifting from mythical 'Paradise' image to more critical understandings about divided Europe and selfish member-states. Already being in the EU and NATO, Lithuania should balance sometimes unfriendly westerners' reluctance to understand the situation and help against Russia with the economic power that Russia uses as a political instrument against Lithuania on the international arena, as well as in domestic politics. This results in the feelings of "lost and forgotten" between Europe and Russia. Nevertheless, Europe continues to earn a positive meaning in national collective identity of Lithuanians, but all these trends in public discourse show that the state and society have only just started to realize its interests and learn how to handle the major challenges through the cooperation within the European Union, i.e. to build integrational European identity.

\section{Rezumat:}

"Europa" și „Rusia" au fost, din perspectivă istorică, reperele cele mai remarcabile ce au avut funcții de călăuze geopolitice, culturale și morale in conturarea identităților naționale colective din țările Europei Central-Răsăritene, acest lucru fiind valabil și pentru Lituania. Această identitate "civilizațională" a unit elitele politice și societatea lituaniană în procesul de apropiere de Occident și Europa demarat după colapsul Uniunii Sovietice. Problematica pe care o ridică acest articol este în ce măsură apartenența la Uniunea Europeană de la 1 mai 2004 a avut consecințe asupra redefinirii "Europei" și a "Rusiei" ca vechi ingrediente substanțiale ale identității colective a lituanienilor. Articolul realizează o cercetare bazată pe analiza discursului public național din cinci ziare lituaniene din anii 2004-2007, cuprinzând un interval de trei ani de apartenență la U.E. şi N.A.T.O. Principalul rezultat al cercetării este concluzia că rolul Rusiei in identitatea colectivă lituaniană nu s-a schimbat şi continuă să fie perceput ca principala amenințare. Potrivit acestei percepții, Rusia a început să pătrundă treptat în economia lituaniană (în special în sectorul energetic) și pe nevăzute a pornit a avea un impact asupra partidelor și a elitei politice. Pe de altă parte, rolul tradițional al Europei se transformă treptat din imaginea unui paradis ",mitic" în direcția unei înțelegeri mai critice cu privire la divizarea acesteia și la statele membre egoiste. Deja parte componentă a U.E. și a N.A.T.O., Lituania trebuie să găsească un echilibru între reținerea câteodată a occidentalilor nefavorabili de a înțelege situația și de a acorda ajutor impotriva Rusiei şi puterea economică pe care aceasta din urmă o proiectează ca instrument politic împotriva Lituaniei atât pe arena internațională cât și $\hat{i}$ politicile interne. Aceasta are ca rezultantă sentimentul de "pierdută și uitată" între Europa și Rusia. Totuși, Europa continuă să aibă o semnificație pozitivă în identitatea colectivă a lituanienilor, dar toate aceste tendințe din discursul public arată că statul și societatea abia au 
inceput să-și realizeze interesele și să învețe cum să abordeze principalele provocări prin cooperare сu U.E., constituindu-și o identitate europeană integratoare.

Keywords: Lithuania, national collective identity, public discourse, Central Eastern Europe, European Union, Russia, civilizational identity, integrational identity

\section{National and European identities in Central Eastern Europe - historical outline}

In the European studies national collective identities are being analysed as a constitutive part of European identity and vice versa. Starting from the beginning of the first decade of this century numerous studies have appeared on the national collective identities of various member states. ${ }^{2}$ The significance to study them was perhaps the best summed up by Thomas Risse: "the evidence suggests that socialization into European identity works not so much through transnational processes or through exposure to European institutions, but on the national levels in a process whereby Europeanness or 'becoming European' is gradually being embedded in understandings of national identities". ${ }^{3}$ According to this wing of literature, the national identities play the crucial role to shape the process of European identity formation, since 'Europe' is immersed in the national identity construction.

2 Thomas Risse, “A European Identity? Europeanization and the Evolution of Nation-State Identities', in Transforming Europe. Europeanization and Domestic Change, eds. M. Green Cowles, J. A. Caporaso, Th. Risse (Ithaca, NY: Cornell University Press, 2001); Mikael af Malmborg and Bo Sträth, The Meaning of Europe (Oxford International Publishers Ltd., 2002); Klaus Eder and Willfried Spohn, eds., Collective Memory and European Identity (Anthony Rowe Ltd., 2005); Willfried Spohn and Anna Triandafyllidou, eds., Europeanization, National Identities and Migration (London: Routledge, 2003); Juan Diez Medrano, Framing Europe: Attitudes to European Integration in Germany, Spain, and the United Kingdom (Princeton, NJ: Princeton University Press, 2003); Atsuko Ichijo and Willfried Spohn, eds., Entangled Identities. Nations and Europe (Athenaem Press Ltd., 2005); Ireneusz P. Karolewski and Viktoria Kaina, eds., European Identity. Theorethical Perspectives and Emprirical Insights (Berlin: Lit Verlag, 2006); Richard Robyn, ed., The Changing Face of European Identity (New York: Routledge, 2005); Petr Drulak, ed., National and European Identities in the EU Enlargement. Views from Central and Eastern Europe (Prague: Institute for International Relations, 2001).

3 Thomas Risse, "Neofunctionalism, European Identity, and the Puzzles of European Integration", Journal of European Public Policy 12, no. 2 (2005): 291. 
What kind of 'Europe' was inherent in national identities of Central Eastern Europe?

What is historically common for the new EU member states from Central Eastern Europe is a civilizational European identity ${ }^{4}$ which stems from historical perception of backwardness compared to Western Europe resulted from Russia and eventually Soviet imperialistic aggression. The Central European national collective identities are commonly prescribed two essential features: orientation to Europe as a sole road to modernity, democracy, safety, and prosperity, and secondly, a perceived danger of Russia stemming from the soviet period (or more deep history) and bearing a collective historical trauma. A famous Milan Kundera's ${ }^{5}$ note on tragedy of Central Europe gives an example of such essential distinction between Central Europe that has always been a part of Western civilization and Eastern Europe and Russia that kidnapped Central European countries from their natural house - Europe. For this reason Europe has always been imagined as a space of shared cultural, political, civilizational values with Central European countries and Baltic States. Only in this historical and geopolitical context we can understand the moral argument that was expressed in these countries after the collapse of communism that now Europe should implement historical justice and guarantee their return to Europe. Europe's periphery, grey zone, being 'in-between' are the most remarkable negative traits in the common understandings of this region.

In Lithuanian case, 'Europe' or 'West' has been imagined in the national collective identity as safety and prosperity zone, where the small nations can reach protection from Eastern imperial powers (Russia). European identity of the Lithuanians has always been strong in geopolitical and cultural terms of 'belonging to Europe'. Each national movement and fight for independence against occupant Russia (tsarist or soviet) in the $19^{\text {th }}-20^{\text {th }}$ century embraced the idea to be a part of Europe. European element was evidently present in the fighting for independence at the time of collapsing Soviet Union in 1988-1993 either, when a motive to return to Europe from soviet terror was an inseparable part of Lithuanian freedom.

\footnotetext{
4 Willfried Spohn, "National Identities and Collective Memory in an Enlarged Europe", in Collective Memory and European Identity, eds. Klaus Eder and Willfried Spohn (Anthony Rowe Ltd., 2005)

${ }^{5}$ Milan Kundera, 'The tragedy of Central Europe', New York Review of Books, 26 April 1984: 33-38. 
Europe and Lithuania's independence then, as always, was tightly connected. Such massive support of the society to fight for independence and to take a pro-European course was an evidence how deeply civilizational European identity predominated in the national understandings of Lithuanians. This course proceeded continued until the joining to the EU in 2004 even in the former communists (subsequently social democrats) governmental terms. This can be explained by a long and strong post-war resistance movement directed against soviet rule and the collective memory (pride) of interwar sovereignty.

Thus 'Europe' and 'Russia' are the most remarkable landmarks for the Central Eastern European countries' collective identities, including Lithuania. They mean always more than just territorial, geographical images. Both therefore have been playing historical, geopolitical, cultural, and moral guide-role in the construction of national collective identities.

\section{Theoretical Guidelines and Premises}

This research is theoretically guided by the distinction of civilizational and integrational identity encompassing and comparing Central Eastern Europeans and Western Europeans, as Wilfried Spohn underlined. ${ }^{6}$ According to it, Central Eastern European countries such as Lithuania grounded its pro-European course after the collapse of Soviet Union in the conception of a deep civilizational European identity which contained the feelings of historically belonging to Europe as well as being pulled out from Europe by Russia's aggression. Joining Europe was supposed to be the moral return to the same space of cultural-political values and to get the shield of protection against Russia. The integrational identity, however, means that member states have been forming their common representations on successful economic and political cooperation. Integrational identity, as Spohn notices, is typical to the older member states of the EU which have been experiencing common integration since the 1950's that has ensured lasting peace and social welfare for their citizens. Both types of identity perhaps might not be mutually exclusive, but refer just to the different bases of national common representations.

\footnotetext{
6 Spohn 2005; Klaus Eder calls this distinction as core Europeans/peripheral or not-yet Europeans, Klaus Eder, "Remembering National Memories Together: The Formation of a Transnational Identity in Europe", in Eder and Spohn 2005, 201.
} 
As noted, a civilizational identity has played the most prominent role to Lithuania in taking pro-European course after the collapse of Soviet Union in the 1990's when it helped unite Lithuanian political elites as well as society towards the direction towards West and Europe. ${ }^{7}$ Based on it Lithuanian official diplomacy declared three strategic goals in foreign and security politics in 1994: to enter NATO, to join EU, and to maintain close partnership with the neighbour states.

After the vital interest was fulfilled on May 1st, 2004, the new social and political experiences started with migration without borders within the $\mathrm{EU}$, political participation in the EU institutions, doing business and making contacts across various social levels, in sum - facing the inner kitchen of European political, institutional, social and economic life.

The distinction on civilizational/integrational identities may explain the possible change in the national identities of the new member states: does the membership de facto in the EU initiate some changes in the traditional understanding of Lithuanians? To put it simply, if Europe had been assumed as protection from Russia while Lithuania was out of the European borders, it is reasonable to think that factual being within Europe may, at some extent at least, help to diminish the perceived threat from Russia. Or, seen from the other side, while trying to become a member of

\footnotetext{
7 Inga Pavlovaitè, "Paradise Regained: the Conceptualisation of Europe in the Lithuanian Debate", in Post-Cold War Identity Politics. Northern and Baltic Experiences, eds. Marko Lehti and David J. Smith (London: Frank Cass Publishers, 2003), Inga Vinogradnaitė,"The Construction of National and European Identity in Lithuania", in National and European Identities in the EU Enlargement. Views from Central and Eastern Europe, ed. Petr Drulak (Prague: Institute for International Relations, 2001). Actually, this civilizational European identity of Lithuanians certainly carried some mythical elements, due to the fact that Europe or West was idealized only in positive manner. 'Return to Europe' motive hided deeper syndromes of national grievances suffered from soviet terror, like lost freedom, oppressed by alien soviet rule, lost and forgotten, stopped natural development of the nation and the state, backwardness, even being betrayed by West. Europe was a historical receipt to all national misfortunes. When frustrated past is automatically replaced and moved on the shoulders of the other goodness ('Europe'), such subconsciously working ideology is condemned to fail sooner or later. The first shock came soon from the real post-soviet developments which showed that 'return to Europe' has more to do with painful economic, social, and democratic reforms, rather than with automatic jump into the paradise. Introduction of free market and liberal democracy, associated with the direction to Europe and West, brought the majority of people in harsh social condition. Nevertheless, the support to 'Europe' remained steadfast considering social troubles as inevitable costs for being independent.
} 
the European family is easy to perceive Europe only in a positive manner (thus justifying the strategic task to join), but maybe the reality that the state and society is facing being within the EU is forcing somehow to reorientate the traditional positive outlook to Europe as 'paradise' or to strengthen it?

The distinction between civilizational/integrational European identity helps to state the general question in our research: does the factual belonging to the European Union after the May 1st, 2004 give the impact to re-define 'Europe' and 'Russia' (the old essentials of civilizational European identity)? Or to continue with, does Lithuanian national identity acquire the features of integrational European identity, i.e. these traditional guidelines of Russia and Europe are being represented by referring to the new experience of European integration? In other words, whether and how (if at all) is Lithuanian collective identity being Europeanized after the accession?

It is fairly difficult, actually, to anticipate the radical change in the short period of membership, especially comparing with such a long period of hopes to return to Europe. But still, actual being within the Union and among the other and older western European states is likely to make a certain new experience and probable changes in national perceptions.

\section{Methodological Design and Data Collection}

In order to reveal the possible shift in Lithuanian collective identity the national public discourse is explored in this research. The relevance of public discourse in shaping national identity is well stated in the academic field. ${ }^{8}$ As long as the nation has been imagined through "print capitalism" , i.e. newspapers, magazines, books, the same function of the public sphere in sustaining national narrative is visible today. Political, cultural, historical ideas about the nation and Europe are especially contested in the public

\footnotetext{
${ }^{8}$ Michal Krzyzanowski, The Discursive Construction of European Identities (Frankfurt am Main: Peter Lang GmbH., 2010); Ljiljana Šarič et al., eds., Contesting Europe's Eastern Rim. Cultural Identities in Public Discourse (Toronto: Multulingual Matters, 2010); Thomas Risse, A Community of Europeans? Transnational Identities and Public Spheres (Ithaca and London: Cornell University Press, 2010); Jürgen Habermas, 'The European Nation-state: On the Past and Future of Sovereignty and Citizenship', Public Culture 10, No. 2 (1998): 397-416; Jürgen Habermas, The Postnational Constellation: Political Essays, transl., edited, and introd. by Max Pensky (Cambridge: MIT Press, 2001).

${ }_{9}^{9}$ Benedict Anderson, Imagined Communities: Reflections on the Origin and Spread of Nationalism (London: Verso, 1983).
} 
sphere where different discourses meet, fight and thereby construct the national and European identity.

The monitoring of national mass media covered the second half of 2004 year (starting from the $1^{\text {st }}$ May - the membership date for the many Central Eastern European countries), 2005, 2006, and 2007 years. Four national Lithuanian newspapers were selected: "Lietuvos rytas" (transl. in English "Lithuanian Morning"; “Respublika”, transl. "Republic"); Lietuvos žinios", transl. "News of Lithuania"; "Vakaro žinios", transl. "Evening news") and one week-journal ("Veidas", transl. "Face"). Differently from other newspapers these media are the only ones which cover all the territory of the state, and the entire population of Lithuania in outermost territorial corners can order, buy and read them.

At first, the articles were selected through key words such as "Europe“, „European Union“, ,Russia“, ,national interests-values-threats", "national/European identity“ etc. (quantitative screening). In sum 418 media articles and reports were selected. Then the content of the selected articles was analysed by crystallizing the basic message they wished to transfer to the reader (qualitative analysis). Discourse content analysis allows to disclose exact meaning (seeing the whole view of images, photos, headers and sub headers) that media wants to transfer to the audience and form the perceptions of readers. Based on the content all they were put into thematic boxes.

The articles on Russia are divided into two opinions, perceiving it as a threat or as a partner that does not constitute a danger. Articles on Europe (the EU) split into three directions: neutral information and news concerning the EU; the conviction that the EU and NATO (both as 'West') are not homogenous and are deeply divided into selfish member-states; and the image of the EU and NATO as the Lithuanian road to modernization. The articles on Lithuania's role and national vision were framed into these themes: those whose main concern was to focus on national and European identity as such; internal (civil, social) security of the state; those which expressed the idea about Lithuania as mediator between West and East. Some themes were visible but occupied quite small segment of public discourse: Lithuania's bilateral relationship with other countries; disappointment about Lithuania's dependency on other mighty countries; euro-scepticism; emigration; Lithuania's backwardness; and Lithuania in the regions. 
These are the most remarkable themes regarding national collective identity in the Lithuanian national newspapers between May 1st, 2004 December 31st, 2007 summarized in table 1. The percentage indicates the part of public discourse - the attention to a certain theme, which is converted from the amount of articles, for example, the conviction about Russia as a threat occupies $26.31 \%$ or 110 articles from total 418 articles of national public discourse.

Table 1. Basic Themes in Lithuanian Public Discourse in 20042007 on National and European Identities

\begin{tabular}{|l|c|}
\hline \multicolumn{1}{|c|}{ Theme } & $\begin{array}{c}\text { Percentage of the public } \\
\text { discourse (linked to the amount } \\
\text { of articles) }\end{array}$ \\
\hline Factor of Russia (danger) & 26.31 \\
\hline National and European identity & 16.26 \\
\hline $\begin{array}{l}\text { European Union (news, events, } \\
\text { statistics on public opinion) }\end{array}$ & 12,91 \\
\hline Internal (civil, social) security & 8.61 \\
\hline $\begin{array}{l}\text { West (ES and NATO) are not } \\
\text { homogenous }\end{array}$ & 8.61 \\
\hline $\begin{array}{l}\text { Lithuania - mediator between } \\
\text { democratic West and non-democratic } \\
\text { East }\end{array}$ & 6.22 \\
\hline $\begin{array}{l}\text { EU and NATO as a road to } \\
\text { modernization, } \\
\text { prosperity }\end{array}$ & 3.82 \\
\hline $\begin{array}{l}\text { Bilateral relations with neighbour } \\
\text { countries (Poland, Belorussia, Sweden) }\end{array}$ & 3.34 \\
\hline $\begin{array}{l}\text { Lithuania - exchange object for the } \\
\text { mighty countries }\end{array}$ & 2.87 \\
\hline Euro-scepticism & 2.63 \\
\hline Emigration & 2.39 \\
\hline Russia doesn't make a threat & 2.15 \\
\hline Lithuanian backwardness regions (North; \\
\hline $\begin{array}{l}\text { Lithuania in the } \\
\text { Central Eastern Europe) }\end{array}$ & 0.71 \\
\hline
\end{tabular}




\begin{tabular}{|l|r}
\hline Others & 2.45 \\
\hline
\end{tabular}

\section{Results}

\section{Russia}

Russia statistically occupies the biggest part of attention (26.31\%) and still continues to constitute a hazard in the Lithuanian public discourses regarding national security, even in the times when the state has been already enjoying membership in NATO and the EU. This is a traditional and stable representation in Lithuanian national and European identity, determined by a long time historical experience of occupation. At first look, it can be a little surprise because of the fact that three and a half year membership in the EU and NATO has not reduced the perception of Russian danger at all. Paradoxically, by analysing the ideas and arguments presented in newspapers we can see that the perception of Russia as a threat not only that it has not disappeared, but to the contrary, it became even stronger. The reason is that Russia, according to the mass media, began to express its interest in the Baltic States more actively but secretly compared to an open objection to the NATO membership of Baltic States in the 1990s. Before the Baltic nations entered the Western organizations Russia acted with an explicit discontent. Now, since they are within the EU and NATO, Russia's behaviour has changed from open pressure to the more subtle and hidden actions. Three key concerns are evident in Lithuanian public discourse about Russia's impact into domestic affairs of the state: a) silent economical intervention of Russian capital into national enterprises of strategic importance, mostly in the energy sector (electricity, gas, and oil); b) hidden impact on the Lithuanian politicians and some parties, and c) informational propaganda through TV channels that Russia controls.

"Russia, starting from the total control of strategic Lithuanian economy sectors, will soon begin to dictate the political decisions of the state"(Respublika, 2005.04.12).

"Russia has obviously been using its energy monopoly power trying to affect post-soviet states politics. ...This is making a negative impact to the development of democracy and free market in these countries" (Lietuvos žinios, 2004.11.18). 
„In the Lithuanian domestic politics there are plenty of persons who are closely related with the Russian energy clans. They are making impact to the Lithuanian politicians" (Lietuvos rytas, 2005.03.22)

"It is difficult to understand, why in Lithuania is freely being broadcasted a fierce propaganda against our state" (Lietuvos rytas, 2005.06.16).

The political scandal involving President Rolandas Paksas in 2003 and 2004, when for the first time in modern European history President of a state was forced to resign by the decision of Constitutional Court, was actually grounded in accusations of Chief of State's shady relations with Russian security agencies and business representatives (Jurij Borisov).

Doubts yet about Darbo partija (Labour Party) - one of the biggest parties - ambiguous connections with Russia, especially through a party's leader Viktor Uspaskich, Russian origin politician has not been dispelled. Actually, these two parties - "Tvarka ir teisingumas" ("Order and justice", leader Rolandas Paksas) and the Labour Party are likely going to form governing majority in the Parliament after the elections of October 2012.

Potential and real harmful penetration of Russian economic and political power into national domestic affairs is complemented by Russia's malicious actions against Lithuania's national interests on the international arena. And here Lithuania falls in a particularly unfavourable situation. National newspapers points to Russia's insidious game played in the international relations by trying to make bilateral relationship with the biggest member states of the EU (Germany, France, Italy), usually built upon a personal Vladimir Putin's friendship with the European leaders (Gerhard Schröder, Silvio Berlusconi). The result is disastrous to Lithuania: the strategic national hopes to achieve protection from the EU against Russia fade away. Lithuania loses the support it has always wished to have from Europe. And moreover, Lithuania deserves a bothersome tiny state image in the eyes of Western partners when trying to raise a question of Russian unfriendly interests. Lithuania with its focus on the continuity of Russian imperialistic politics in Eastern Europe becomes alone and misunderstood in Western Europe. Russia exploits this situation on its turn making attempts on each occasion to create a nationalistic image of Baltic States as if they hate Russia only because of narrow nationalistic (even Nazi-like) motives that are so unpleasant to Western Europeans.

All these anxieties are best summarized in this citation: 
Under the conditions of globalization the methods of foreign affairs politics are changing: in order to make Lithuania its vassal Russia can overmaster national energy sector, public sphere of information and other fields. ... In the Lithuanian energy sector Russia uses a strategy of total domination, i.e. creates a vertical control of Lithuanian energy sector. The enterprises controlled by Russian capital may become the means of political pressure by Moscow. Besides, this can result in inosculation of Russian capital and Lithuanian political elites. Invoking its people in the political parties and state's institutions Russia is able to affect the political processes in our state. More noteworthy is that Russia disposes of possibility to influence Lithuania through NATO and EU structures or by trying to trigger the inner erosion of those organizations. ... Russia grounds the relationship with EU and NATO on double strategy: either tries to restrict the influence of these organizations on the certain questions of international politics that are relevant to Russia, or pursues to penetrate into a decisionmaking of these institutions. The second direction of Russian politics on EU and NATO, namely, is the most dangerous to Lithuania. ... Given to these new security dilemmas of Lithuania, we can conclude that the membership of NATO and EU has not yet eliminated the European periphery-state status of Lithuania (Veidas, 2007.08.23).

On the other hand, Russia is too big, too near, and too economically powerful to allow Lithuania or any other Central Eastern European state display open confrontation tone with it. The idea that it would be useful to maintain at least pragmatic relations with Russia, seeking to obtain as much economic benefit as possible, is alive in the discourse of some politicians, business representatives, political observers, and economists. But it occupies only unusually small part $(2.15 \%)$ of the observed articles and far to outweigh a fundamental geopolitical danger.

It is extremely difficult if not impossible to find an open and firm statement in Lithuanian public discourses about Russia as friendly, democratic neighbour, whose interests coincide with the Lithuanian national interests. 


\section{The EU and the NATO}

As it has been expected, an outsider image of the unproblematic, homogenously positive Western civilization has been gradually replaced by ideas endemic to a more closed-distance look. It can be noted, however, that traditional image of Europe as the springboard of modernization, economic benefit, safety and prosperity zone still exists in the public discourse of Lithuanians, but is only of $3.82 \%$ in magnitude. It is certainly not the same as it has been after independence restoration in the 1990s. Now it is obviously outweighed by more informed outlook that in the EU exist different national interests that are not necessarily favourable to Lithuania's goals; that the EU and the NATO are not homogenous organizations with the uniform will and without any problems inside; that in these Western organizations the state should stand for its national interests, that the best way to defend them is to cooperate with the other allied states within organization. This view takes $8.61 \%$ of monitored public discourse. The most painful expressions relate to the understanding of inner disunity of the EU:

„European Union does not care about the peace of Baltic. ... Finally, Lithuanian politicians opened their eyes [to the fact] that the older memberstates of the EU care only for their interests, and not for the Baltic states' interests" (Vakaro žinios 2007.05.10).

Discussion about the EU's matters in Seimas (Parliament) has revealed that Lithuanian officials have already begun to criticize more openly the EU. But it took for a shameful meeting of EU leaders in June that the member-states have starkly scrimmaged for money and willingly showed how deeply divided and how on national interests grounded is this club ... The EU has always been mostly a national interest's based union of the states. ... It is time to fight seriously for our own interests. In the EU arena however play big figures, so we need to seek their support (Veidas, 2005.10.27).

Sometimes there is a certain disappointment that big states in the EU and NATO do not understand the needs of small countries from 
Central Eastern Europe or they have fairly different interests than Lithuania:

„New maps are drawn behind our backs, and we are kept only as exchange objects" (Respublika, 2004. 05.31).

"State's membership in NATO is beneficial but provides relative security guarantee only. If required, it would always be found a pretext to betray the new member states referring to the "higher" goal" (Veidas, 2006.10.19).

Notably, the understanding about the selfish interests of the member-states in the EU does not go in line with euro-scepticism that "we do not need such European Union". Instead of the populist idea about the $\mathrm{EU}$ as an evil, this position rather reflects the EU reality Lithuania has faced, and invites to adopt and learn quickly how to defend the national interest. In this view EU is stably continuing to be a guarantee of modernization, safety, prosperity, and democracy for Lithuania. What is new in the image of Europe - it is a change from uncritical view about homogenous, democratic, stable and safe Europe (civilizational identity) to a view about divided Europe which is torn by selfish interests of memberstates (integrational identity). A look from outside is gradually being replaced by a look from inside.

The same applies to an evaluation of NATO where some influential members (France, Germany) do like to oppose the United States and do not avoid the friendship with Russia, for example, in the case of Iraq war. French president's Jacques Chirac proposal in 2003 to the new candidates in Eastern Europe to shut up (,they missed the perfect opportunity to shut up") probably added awareness to the Eastern Europeans about the cleavage between West and Eastern Europe, or between ,old' and "new' Europe (as Donald Rumsfeld commented in January 2003). The reaction in Lithuanian mass media then was emotionally taking offense comparing with today's rational understanding about the different and selfish interests that are fighting in the EU and the NATO. It is difficult to properly evaluate to what extent Lithuanian diplomats, politicians and experts are deeply involved and do comprehend the rules of real political clashes, how to make coalitions, to defend positions and to reach compromise - about all this real political game between states that is usually invisible to the ordinary eyes. From the observation of Lithuanian public discourse during first three years and a half of membership one can make up an opinion that 
Lithuanians' awareness about the specific interests of the particular member states is feeble. The newspapers and experts' comments provide only general suspicions about the disunity of the EU, sometimes about the different vision of EU held by the UK, France and Germany. This means that Lithuanians have just begun to discover the inner kitchen of the EU and NATO.

Nevertheless, cognition of heterogeneity inside the Western political and security structures does not prevent a positive evaluation of them. The real danger of Russia (the largest part of monitored public discourse) is accompanied by a conviction that partners in the West (NATO and the EU) ensure military, political, and to a lesser extent, economical protection against Russia.

"Lithuania should use the membership in the EU and NATO as a tool to construct its relationship with the biggest neighbour it has" (Lietuvos rytas, 2004.07.03).

„The pressure from Russia is becoming only stronger. ... Now, when we are already equal members of Euro-Atlantic community we will have new possibilities to solve our specific problems in the relationship with Russia" (Lietuvos rytas, 2004.07.08).

Populist critique of the EU and the US certainly does exist in Lithuanian public discourse, but it is slight and bears superficial character. Moreover, the argument is directed not so much against the EU or the US, as on Lithuanian politicians who, according to this argument, are extremely humble and panders to the interests of the others - mighty organizations or states.

"Lithuanian government is a pawn of not only Europe, but of Russia, the United States and of someone else" (Respublika, 2005.09.16).

Therefore we need to ask ourselves, why did we enter to such a NATO? While entering we were seeing one threat from East, to fight against which the alliance was created. For now, however, NATO is becoming a friend to Russia, and Lithuania, which wished to get protection from mighty alliance, is forced to bring ,higher culture' to Afghanistan (Respublika, 2006.10.03).

Euro-scepticism can be found only in two of five Lithuanian national newspapers - "Respublika" and its younger fellow (belonging to 
the same publishing group) tabloid-populist "Evening news" - both are famous for the openly expressed nationalistic and homophobic sentiments. Populist scepticism against the EU takes only $2.39 \%$ of the screened public field.

The news about the EU and Lithuania in the EU of various kinds occupies the third biggest share in the national public discourse $(12.91 \%)$. This flow of news cover such sub-themes as: public opinion across European countries as well as a comparison between Lithuanian society and others member states; how Lithuania manages to use money received from European financial funds; how do Lithuanian MEPs work at the European Parliament; interviews with officials of the EU at various levels and ambassadors of different member states designated to Lithuania; various politicians', experts' and observers' comments on the EU and on Lithuania activities in it etc. All this multi-coloured discourses might witness the gradual penetration of Europe into Lithuanian public sphere. Even if such news are only entering the public field without forming any deep attitude of public opinion, their existence can witness a slow but visible process of becoming European of the Lithuanian society. Maybe it is not still enough and one could expect more, but this bears evidence that Lithuania-Europe connections become closer to a Lithuanian reader.

The issue about how to promote democracy in the eastern borders of EU (6.22\%) helps Lithuanian diplomacy to form its identity after the goal to be in the EU and NATO is achieved, though it earns more critique than approval in national public sphere.

\section{Lithuanian and European identity}

Regarding national and European identity there are two opposite attitudes in Lithuanian public sphere almost equal in length: a concern about the challenge to the national culture or identity, and a conviction that being in the EU is not going to make troubles to the national culture. Those who are not so critical on global impacts of cultural and social flows, develop an argument about positive implications Lithuanian society potentially may gain from being in the EU. To be open to Europe and to the world means possibilities to strengthen national identity or to overcome own syndromes and mental complexes or simply to feel European. Europe and globalization mean the opportunity to become modern by travelling, acquiring knowledge of different cultures, studying and working 
experience, creating and involving oneself in the new social networks, in other words - reaffirm one's national and cultural identity in a new global (European) context. I would call this position a liberal individualistic approach to the national and European identity.

"European Union is not 'bugaboo' to our culture, but a tool to reflect ourselves and thus to strengthen our identity" (Lietuvos žinios 2004.05.15)

„Lithuanian culture will not disappear in Europe. We will be able to master at home by ourselves self-dependently. Europe is united by its common cultural values" (Veidas, 2004.05.27).

Those who think about the negative challenges are trying to develop an argument about the negative impact of alien cultures that diminishes original Lithuanian language, culture and identity. Globalization, free market absolutism and emigration of the people are the most quoted causes that pose a danger to Lithuanian national identity. Sometimes Lithuania is regarded as a province of Europe in terms of morals, political culture, or cultural values: „Lithuania is a spiritual province of Europe“ (Lietuvos žinios, 2005.01.03).

"After Lithuania has become a member of the EU we are feeling much more the processes of globalization that makes the nations uniform" (Lietuvos žinios 2006.07.24).

"Globalization pulls out a human from his roots. This forced freedom is amoral. Market fundamentalism enslaves not only political or national, but even ethical principles" (Respublika 2006.03.03).

„By emigration to the EU, Lithuanian nation is decreasing faster" (Veidas, 2006.07.26).

This critical position I would call the traditionalists or the proponents of a closed nation, since they wish to secure a nation and national identity from the influences of other cultures assuming national identity as sterile cultural essence (language, traditions) that is worth to conserve. What is akin to the traditionalists' attitudes is the willingness to blame the EU for the social problems Lithuanian society confronts, like the rising of prices and emigration. Also, they express dissatisfaction of foreign affairs politics and politicians for their attempt to surrender to the will of westerners (the EU and NATO): "Defending their interests the westerners assault on our national values" (Respublika 2004.11.25). 
In sum, in traditionalists' vision of national and European identity dominate: a general nationalistic concern about the survival of national cultural uniqueness; a construction of a threat coming from West (including social problems); the lack of strong national politics which would resist the more global and stronger powers.

On the other token, discourse on the danger that globalization, emigration, or the existence in the EU is forming for Lithuanian national identity refers to the general risk and usually does not provide more articulated empirical arguments. In addition to this weakness, there is no systematic concern about emigration in Lithuanian public sphere of 20042007 years $(2.39 \%)$, though statistically Lithuania suffers from the biggest flow of emigration among the member states of the EU. Attention to globalization's positive or negative implications is marginal altogether.

\section{Internal (social, civil) security}

This theme constitutes not a huge but still clearly visible part of Lithuanian public debates $(8.61 \%)$. The main argument stated in this field concerns the need for national politics to implement social reforms faster in order to improve the conditions and living standards for the people. The proponents of this view are paying attention to turn foreign and domestic politics to the primary and the most fundamental task of the state: to ensure social security. Only through social or civil security the trust between society and state can be built. Often in this discourse civil security is regarded as the true remedy against the obscure insecurity at the international relations level where major forces are not dependent on Lithuanians' will. In the domestic field the state can and should orientate the politics to improve social conditions and strengthen civil engagement of the society. Sometimes here we can find an astonishing argument that internal security is more valuable than military protection of NATO or than the danger coming from outside, the fear of Russia included.

"If the Lithuanian government wants transparency and harmony to prevail in domestic politics, no Eastern influence can defeat us" (Veidas, 2007.05.17).

„What else except of NATO fighters does protect Lithuanian man? ... The military protection is far from being enough - we need consistency in the state politics in economics, social sphere, culture, education and 
science, to ensure the internal security through the environmental, health insurance politics" (Lietuvos rytas 2005.08.29).

Following this argument, Lithuania should use its membership in the EU to create the welfare to its citizens:

Lithuanian government has no vision of what should it try to achieve in the EU. ... All the years of independence sought the EU membership should not be an end in itself. We must always remember the basic purpose for which our country joined the EU. This is our goal to use the economic opportunities of the internal market to ensure the well-being growth of all the peoples (Lietuvos rytas, 2005.10.24).

Serious concern is expressed regarding inner erosion of democracy and civil society, resulting from the post-soviet process of social transformations. Revolution of independence during the collapse of the Soviet Union in 1989-1991 resulted in the creation of democratic institutions with the general elections to the national parliaments, legally introduced free market rules, freedom of speech, human rights etc. Entrance to the the EU and NATO in 2004 was the best evidence that Lithuania had acquired the basic standards of democracy. Without denying these achievements, mass media additionally stresses the internal problems the democratic system has faced. These problems are pictured as the danger coming not from evidently outside, for instance, from Russia, but undetectably from the inner social processes of consolidating power in the sectors of the political system, economics, judiciary system, mass media, academic sectors or a symbiotic combinations of them. The result is the alienation between state and society. A new democratic system of Lithuania has taken a post-soviet profile "democracy without citizens" or "justice without the people". This process has deserved the attention in the public discourse as the inner danger that challenges security of the state:

"So our biggest problem is the deficiency of active civil and primary communities, both territorial, and functional and professional. Without it, our democracy becomes a formal procedure for the observation of democracy, instead of being a participating democracy" (Veidas, 2006.01.19).

"Democracy without citizens is democracy of only the bureaucrats, who have already learned how to use it“ (Veidas, 2005.09.01). 
"The alienation between the government and the citizens is the main reason why the political identity has not being formed" (Lietuvos rytas, 2006.03.24).

In short, this part of public discourse focuses on home duty that political will has to accomplish with the help of the EU. It raises understanding that a healthy civil society and democracy of the people actually constitutes the basis of real security and for further tasks the state sets sights on.

\section{Conclusions}

The main task of this research was to find out whether the deeper involvement in the European integration after the entrance to the European Union in 2004 does affect the transformation of Lithuanian collective identity. The premise for such expectation was the distinction between civilizational/integrational European identities. ${ }^{10}$ Thus the research question was whether and how does the participation in common economic and political cooperation (the EU) affect the national collective identity of Lithuanians, especially in terms of two basic constitutive parts: Europe and Russia.

The analysis of Lithuanian public discourse of 2004-2007 revealed, that the traditional role of Russia as a historical threat and imperialistic power did not disappear from Lithuanian collective representations, but became even stronger. Instead of a danger of direct military intervention, now the major threat, according to Lithuanian public discourse, is coming from the power of Russian economical capital that Russia uses as a political instrument to influence Lithuanian domestic politics. So, in a case of Russia's role, the Lithuanian collective identity continues to display the features of European civilizational identity inasmuch as it perceives Russia as constituting the main threat to the nation; this is partially supported by the still lasting image of the EU - as a moral, political and economic partner to stop eternal imperialistic ambitions of Russia.

The role of 'Europe', however, is changing in terms of rising awareness about the inner division between separate states and their distinct interests. The traditional image of ,Europe' and ,West' as a sphere of security, welfare and the same cultural values, in short - the road to

\footnotetext{
${ }^{10}$ Spohn 2005, Eder 2005. 
modernization, is additionally being supplemented and even outweighed by understanding that ,Europe' is not homogeneous and sometimes is deeply divided into selfish member states. Unwillingness of the EU to understand Russia's threat to the new member states and to form a united political approach against it causes the sharpest disappointment in the Lithuanian public discourse.

The stress on the internal security, that no other forces outside (NATO or the EU) can guarantee state's security but strong civil society, further reduces the unconditional attachment to the idea of Europe as a paradise. The same applies to considerations on exceptional Lithuanian national identity that criticise, though marginally, the negative impact of globalization and international organization such as NATO and the EU for imposing their will in issues which do not correspond with the preservation of national interests and identity.

Finally, all these tendencies may bear witness to the fact that the positive image of Europe and West is gradually shifting from mythical 'Paradise' image to more critical interpretations. However, Europe continues to enjoy a positive meaning in the national collective identity of Lithuanians, but some trends in public discourses witness that it losses the previously unconditional support. And this probably has to be evaluated as a positive development, since the mythical character of civilizational European identity is being replaced by a more realistic awareness of how to deal with major threats coming from the EU and NATO by cooperating with other member states (thus acquiring integrational European identity). 


\section{References:}

Diez Medrano, Juan. Framing Europe: Attitudes to European Integration in Germany, Spain, and the United Kingdom. Princeton, NJ: Princeton University Press, 2003.

Diez Medrano, Juan. „The Public Sphere and the European Union's Political Identity." in European Identity. Eds. Jeffrey T.Checkel and Peter J.Katzenstein. Cambridge University Press, 2009.

Drulak Petr, ed. National and European Identities in the EU Enlargement. Views from Central and Eastern Europe. Prague: Institute for International Relations, 2001.

Eder, Klaus (2005), “Remembering National Memories Together: The Formation of a Transnational Identity in Europe." In Collective Memory and European Identity. Eds. Klaus Eder and Willfried Spohn. Anthony Rowe Ltd., 2005.

Ichijo, Atsuko and Willfried Spohn, eds. Entangled Identities. Nations and Europe. Athenaem Press Ltd., 2005.

Habermas, Jürgen. "The European Nation-state: On the Past and Future of Sovereignty and Citizenship." Public Culture 10, No. 2 (1998): 397416.

Habermas, Jürgen. The Postnational Constellation: Political Essays. Transl., edited, and introd. by Max Pensky. Cambridge: MIT Press, 2001.

Karolewski, Ireneusz P. and Viktoria Kaina, eds. European Identity. Theorethical Perspectives and Emprirical Insights. Berlin: Lit Verlag, 2006.

Kundera, Milan. 'The tragedy of Central Europe'. New York Review of Books, 26 April 1984, 33-38.

Krzyzanowski, Michal. The Discursive Construction of European Identities. Frankfurt am Main: Peter Lang GmbH, 2010.

af Malmborg, Mikael and Bo Sträth. The Meaning of Europe, Oxford International Publishers Ltd, 2002.

Pavlovaitè, Inga. "Paradise Regained: the Conceptualisation of Europe in the Lithuanian Debate." In Post-Cold War Identity Politics. Northern and Baltic Experiences. Eds. Marko Lehti and David J. Smith. London: Frank Cass Publishers, 2003. 
Risse, Thomas. "A European Identity? Europeanization and the Evolution of Nation-State Identities." In Transforming Europe. Europeanization and Domestic Change. Eds. M. Green Cowles, J. A. Caporaso, Th. Risse. Ithaca, NY: Cornell University Press, 2001.

Risse, Thomas. "Neofunctionalism, European Identity, and the Puzzles of European Integration." Journal of European Public Policy 12, No. 2 (2005): 291-309.

Risse, Thomas, A Community of Europeans? Transnational Identities and Public Spheres. Ithaca and London: Cornell University Press, 2010.

Robyn, Richard, ed. The Changing Face of European Identity. New York: Routledge, 2005.

Spohn, Willfried. "National Identities and Collective Memory in an Enlarged Europe", in: Collective Memory and European Identity. Ed. Klaus Eder and Willfried Spohn. Anthony Rowe Ltd., 2005.

Spohn, Willfried and Anna Triandafyllidou, eds. Europeanization, National Identities and Migration. London: Routledge, 2003.

Šarič, Ljiljana, Andreas Musolff, Stefan Manz, Ingrid Hudabiunigg, eds. Contesting Europe's Eastern Rim. Cultural Identities in Public Discourse. Toronto: Multulingual Matters, 2010.

Vinogradnaitè, Inga. "The Construction of National and European Identity in Lithuania." In National and European Identities in the EU Enlargement. Views from Central and Eastern Europe. Ed. Petr Drulak. Prague: Institute for International Relations, 2001. 